\title{
Effect of fibre level, particle size and adaptation period on digestibility and rate of passage as measured at the ileum and in the faeces in the adult rabbit
}

\author{
BY T. GIDENNE \\ Institut National de la Recherche Agronomique, Laboratoire de recherches sur l'élevage du lapin. \\ BP 27, 31326 Castanet-Tolosan, France
}

(Received 7 August 1990-Accepted 25 March 199I)

\begin{abstract}
The use of specific methods other than gravimetric ones to analyse fibre permitted a more precise study of the degradation of cell wall $(\mathrm{CW})$ in the digestive tract. Digesta flow and rate of passage measurements have not been assessed previously in rabbits to investigate fibre digestion and fibre effects simultaneously in the proximal and in the distal segments of the tract. The effect of the level of dietary fibre on ileal and overall digestibility and rate of passage were studied by comparing semi-purified diets containing only one source of $\mathrm{CW}$ (dehydrated lucerne (Medicago sativa) meal) given to adult female rabbits. The effect of fibre particle size and adaptation period were also investigated. Measurements of fibre composition using both colorimetric and gas-liquid chromatographic techniques, showed that large amounts of $(\mathrm{CW})$ were degraded in the caecocolic segments. Increasing dietary fibre level reduced the rate of passage but fibre degradation was increased, at the same time a lower digestive efficiency for energy in the small intestine was found. A small quantity of $\mathrm{CW}$ was apparently degraded before the caecum, assuming that the water-soluble fraction of $\mathrm{CW}$ was essentially implicated. Grinding lucerne meal through a $1 \mathrm{~mm}$ instead of a $3 \mathrm{~mm}$ screen did not improve $\mathrm{CW}$ digestibility in spite of a longer rate of passage in the caeco-colic segments. Adaptation to a high-fibre diet resulted in an higher digestive volume for colon and caecum, related to an improved degradation of $\mathrm{CW}$. Furthermore, digestive efficiency in the small intestine appeared higher for rabbits adapted to a high-fibre diet than that for rabbits initially fed on a low-fibre diet.
\end{abstract}

Fibre: Digestion: Rate of passage: Rabbit

Nutritional effects of dietary fibre in simple-stomached animals generally have been studied in the whole digestive tract of non herbivorous species (e.g. pigs and rats), using faecal digestibility or rate of passage measurements. More recently, there have been some reports on the effects of fibre on digestion in the small intestine of the pig (Fadel et al. 1989; Laplace et al. 1989), but there are no known comparable studies in herbivorous simple-stomached animals (e.g. horse and rabbit). Furthermore, little information is presently available about fibre degradation using precise analytical methods rather than gravimetric methods (Longland et al. 1989; Longstaff \& McNab, 1989).

Evidence for the effect of fibre composition on digestive phenomena was obtained in several studies (Graham et al. 1986; Gidenne, 1987), but no consistent results were obtained on the effect of the level of cell wall $(\mathrm{CW})$ on diet digestion because mixed diets including various fibre sources were used. Also, frequently the particle sizes of $\mathrm{CW}$ were not considered in spite of their role in digestive processes and motility of the tract. In addition, particle size has a particular effect on caeco-colic motility of the rabbit (Bouyssou et al. 1988), and fine particles are delayed in the colon and are brought back to the caecum during the hard faeces excretion phase, as shown by Björnhag (1972). 
Table 1. Composition ( $\mathrm{g} / \mathrm{kg}$ diet) of the experimental diets

\begin{tabular}{|c|c|c|c|c|}
\hline & Diet ... & Low-fibre & High-fibre & $\begin{array}{l}\text { High-fibre } \\
\text { finely ground }\end{array}$ \\
\hline \multicolumn{5}{|l|}{ Ingredients ( $\mathrm{g} / \mathrm{kg}$ diet $)$} \\
\hline Dehydrated lucerne (Medicago sativa) meal & & 485 & 765 & 765 \\
\hline Purified maize starch & & 390 & 166 & 166 \\
\hline Fish-meal concentrate & & 100 & 48 & 48 \\
\hline Minerals and vitamins & & 25 & 21 & 21 \\
\hline Type of grinding & & $3 \mathrm{~mm}$ & $3 \mathrm{~mm}$ & $1 \mathrm{~mm}$ \\
\hline \multicolumn{5}{|l|}{ Chemical composition ( $\mathrm{g} / \mathrm{kg}$ dry matter) } \\
\hline Organic matter & & 912 & 889 & 887 \\
\hline Minerals & & 88 & 111 & 113 \\
\hline Starch & & 353 & 158 & 161 \\
\hline Crude protein (nitrogen $\times 6.25$ ) & & 176 & 182 & 179 \\
\hline Gross energy $(\mathrm{MJ} / \mathrm{kg})$ & & $17 \cdot 64$ & $17 \cdot 54$ & 17.33 \\
\hline NDF & & 236 & 357 & 356 \\
\hline
\end{tabular}

NDF, neutral-detergent fibre.

The purpose of the present study was to provide further information on the effect of fibre level and particle size on digestion in the rabbit small intestine and caeco-colic segment, using a single source of $\mathrm{CW}$ in the diets (dehydrated lucerne (Medicago sativa) meal) to prevent associative effects between the composition and the level of the fibre source. In addition, we also investigated the effect of adaptation to a fibrous diet with growing rabbits on digestive volume and $\mathrm{CW}$ degradation.

\section{MATERIALS AND METHODS}

Diets and animals

Three diets were formulated and given ad lib. in a pelleted form throughout the entire experiment. All diets contained dehydrated lucerne meal (LM) as the only source of $\mathrm{CW}$ (Table 1), fish-concentrate meal and purified maize starch to obtain a similar digestible protein : digestible energy value for the low-fibre $(\mathrm{L})$ and high-fibre $(\mathrm{H})$ diets. Diet $\mathrm{F}$ differed from diet $\mathrm{H}$ in that the $\mathrm{LM}$ was milled through a $1 \mathrm{~mm}$ instead of a $3 \mathrm{~mm}$ screen. Before pelleting, each diet was divided into two batches, one being supplemented $(9.5 \mathrm{~g} / \mathrm{kg})$ with ytterbium-labelled lucerne CW (Ellis \& Beever, 1985). Yb was used in order to perform rate of passage studies and digesta flow measurements at the ileum as described previously by Gidenne \& Ruckebusch (1989). Labelling of the particulate phase with $\mathrm{Yb}$ was sufficient for ileal flow measurements, as shown by Gidenne (1988). Particle sizes in feeds were determined on four samples of pellets by wet sieving (Table 2).

The experiments were carried out with two groups of eighteen weaned (4 weeks old) Californian female rabbits. In each group ten animals were used for digestive volume measurements, and eight animals were used for digestibility measurements and fitted (at 8 weeks old) with a T-shaped glass cannula (Gidenne et al. 1988) about $50 \mathrm{~mm}$ before the ileo-caecal junction in order to perform ileal flow and rate of passage measurements. All animals were housed in individual cages under a $12 \mathrm{~h}-12 \mathrm{~h}$ light-dark schedule.

\section{Adaptation time and digestive volume measurements}

First, diets $\mathrm{L}$ and $\mathrm{H}$ were given for an adaptation period (PO; food intake was assessed twice weekly), from 4 to 11 weeks of age, to the two groups of rabbits $(n 18)$. Then, ten animals from each group were slaughtered by stunning narcosis at about 10.00 hours in 
Table 2. Class of particle size $(\mathrm{g} / \mathrm{kg}$ dry matter) in the experimental diets*

(Mean values and standard deviations)

\begin{tabular}{|c|c|c|c|c|c|c|c|}
\hline \multirow{2}{*}{$\begin{array}{l}\text { Diet... } \\
\text { Particle } \\
\text { size }(\mathrm{mm})\end{array}$} & \multicolumn{2}{|c|}{ Low-fibre } & \multicolumn{2}{|c|}{ High-fibre } & \multicolumn{2}{|c|}{$\begin{array}{l}\text { High-fibre, } \\
\text { finely ground }\end{array}$} & \multirow{2}{*}{$\begin{array}{c}\text { Statistical } \\
\text { significance } \\
\text { of difference: } \\
P\end{array}$} \\
\hline & Mean & SD & Mean & $\mathrm{SD}$ & Mean & SD & \\
\hline$>1$ & $6^{\mathrm{a}}$ & 2 & $15^{\circ}$ & 2 & - & - & $<0.01$ \\
\hline $0 \cdot 5-1$ & $58^{\mathrm{a}}$ & 5 & $103^{b}$ & 6 & $83^{\circ}$ & 9 & $<0.01$ \\
\hline $0.3-0.5$ & $73^{a}$ & 4 & $105^{b}$ & 6 & $107^{\circ}$ & 5 & $<0.01$ \\
\hline$<0.3$ & $863^{a}$ & 4 & $771^{b}$ & 1 & $810^{\circ}$ & 6 & $<0.01$ \\
\hline
\end{tabular}

a,b,c Mean values with different superscript letters in the same line were significantly different $(P<0.05)$.

* For details, see Table 1 and p. 134.

order to measure digesta contents and fresh organ weights for the stomach, caecum and proximal colon. The total digestive tract was removed by severing at the base of the skull. Organs were weighed and then emptied by gentle squeezing. Then they were rinsed clear of contents with water and dried with paper towels.

\section{Digestibility and rate of passage measurements}

Five rabbits from each group of eight ( $\mathrm{L}$ or $\mathrm{H}$ ) were used, from 11 weeks of age, in three periods of digestibility measurements. Animals were chosen according to similar intake and live weight. The same rabbits were used during the three periods, except one animal in each group was replaced after the first period. Groups of rabbits were defined according to dietary treatment: rabbits were initially fed on diets $\mathrm{L}$ or $\mathrm{H}$ in $\mathrm{PO}$, then, in the first period rabbits were fed on the same diets as in PO (group LL and $\mathrm{HH}$ ), in the second period rabbits received diet $F$ (groups $L F$ and $H F$ ), and in the third period rabbits received diets $\mathrm{H}$ or L (groups LH and HL).

Apparent faecal digestibility coefficients (FDC) were calculated, after $7 \mathrm{~d}$ of adaptation, from total collection of faeces during $7 \mathrm{~d}$. Faeces were pooled individually in plastic bags and stored at $-18^{\circ}$ for further analyses. Ileal digesta were collected from the cannula. Six collections ( $1 \mathrm{~h}$ each) were made over a period of $3 \mathrm{~d}$, such that they covered a $24 \mathrm{~h}$ period: $01.00,05.00,09.00,13.00,17.00$ and 21.00 hours. In order to calculate the digestibility coefficient at the ileum (IDC), the total intake (including diet plus soft faeces intake) was determined. Thus, soft faeces excretion was measured in each period and individually for each rabbit wearing a plastic collar during 24 h (Gidenne \& Lebas, 1987).

Rate of passage measurements of Yb-labelled lucerne CW were performed using the same rabbits after digestibility assessment, at the ileum and in the whole tract (Gidenne \& Ruckebusch, 1989). Total faecal collection was fractionated during $56 \mathrm{~h}$ by means of an automatic faecal sampler adapted for use in the metabolism cages. During digestibility and rate of passage measurements food intake was assessed every day.

\section{Chemical analyses}

Dry matter (DM) was determined on duplicate samples by heating at $105^{\circ}$ for $24 \mathrm{~h}$, and all results were calculated on a dry weight basis. Analyses were performed on duplicate freeze dried samples of feeds, soft and hard faeces and ileal digesta. Organic matter (OM) was determined by ashing at $550^{\circ}$ for $5 \mathrm{~h}$. Nitrogen was measured by a Kjeldhal procedure and converted to crude protein using the factor 6.25. Starch was hydrolysed enzymically and the resultant glucose was measured by using the hexokinase (EC 2.7.1.1)-glucose-6- 
phosphate dehydrogenase (NAD) (EC 1.1.1.49) system (Böehringer Mannheim). Gross energy was measured by an adiabatic bomb calorimeter. Neutral-detergent fibre (NDF) was determined according to Van Soest \& Wine (1967) using an amylase (EC 3.2.1.1) and protease (EC 3.4.24.4) treatment (Giger et al. 1979). Water-insoluble non-starch polysaccharides (NSP) in feeds were isolated using amylase and pronase (EC 3.4 .21.4, 3.4.24.4; from Streptomyces griseus) treatments (Carré et al. 1984). The water-soluble NSP of feeds were isolated from supernatant fractions resulting from amylase and pronase treatments using extensive dialysis against water at $4^{\circ}$ (dialysis tubes with 3500 molecular weight cut-off; spectra/Por 3; Poly-labo, Strasbourg). Water soluble and insoluble NSP of faeces were measured as neutral and acidic sugars in residues obtained after amylase and pronase treatments, freezer drying of suspensions, reflux in ethanol-water $(80: 20, \mathrm{v} / \mathrm{v})$ and centrifugation. Starch contamination was assessed on the insoluble NSP fraction and was less than 2 and $6 \mathrm{~g} / \mathrm{kg}$ (NSP dry matter basis) respectively for feed and faeces samples. Neutral sugars of NSP were measured by gas-liquid chromatography analysis of their alditol acetate derivatives (Blakeney et al. 1983). Uronic acids were determined colorimetrically by the $m$-phenyphenol method (Blumenkrantz \& Asboe-Hansen, 1973). $\mathrm{Yb}$ was determined by atomic absorption spectrometry.

\section{Calculations and statistics}

Mean retention time (MRT) values for the whole tract were obtained after a continuous infusion of $\mathrm{Yb}$ had been stopped; the following equation was used: $\mathrm{MRT}=T_{1}+$ $\Sigma A_{i}\left(T_{i+1}-T_{i}\right)$. MRT between ileum and rectum was obtained after single dose administration of $\mathrm{Yb}$, the following equation was used: $\mathrm{MRT}=\Sigma\left(M_{i} T_{i}\right) . T_{1}$ was the time elapsed between the end of feeding labelled diet (TO) and the defaecation for which $A$ first became less than unity, $A_{i}$ was the marker concentration as a proportion of the equilibrium concentration, $T_{i}$ was the time elapsed between $\mathrm{TO}$ and the $i$ th defaecation and $M_{i}$ was the quantity of marker excreted in the $i$ th defaecation (Faichney, 1975).

Analysis of variance was conducted with GLM procedure of Statistical Analysis System (1985) using a split-plot design for determining diet and adaptation period effect.

\section{RESULTS}

As dehydrated LM was the only source of CW in the diet, its NSP composition was deduced from Table 3. Water-soluble NSP represented $120 \mathrm{~g} / \mathrm{kg}$ total NSP. They originated mainly from pectic substances, as water-soluble uronic acids.

\section{Effect of level of dietary $C W(H H \vee L L$ groups)}

From 4 to 11 weeks of age $(\mathrm{PO})$, voluntary food intake of the rabbits increased $(+38 \%)$ as the digestible energy (DE) content of the diets fell: 10.6 and $9.03 \mathrm{MJ} / \mathrm{kg}$ respectively for diets $L$ and $H$. Then, daily weight gain was similar and feed: gain ratio was higher for diet $\mathrm{H}$ (Table 4). Increasing the proportion of LM resulted in a significant increase in the empty weight of the stomach and caecum and also in their digesta content (Table 4).

Diet $\mathrm{H}$ resulted in a lower FDC of OM, energy and crude protein (Table 5). FDC of starch was almost complete whatever the diet. CW digestion was improved with increasing level of CW in the diet. This result was consistent with two different methods of analysis: NDF (method of Van Soest \& Wine, 1967) or determination of total (water-soluble and water-insoluble) NSP by gas-liquid chromatography (Table 6). This increase in CW digestion was mainly due to better digestibility of xylose and glucose units. Xylose, a typical hemicellulose unit, appeared as the least-degraded neutral sugar (15-30\%). Cellulose digestibility was estimated by analysis of non-starch glucose: FDC was about $25-38 \%$. 
Table 3. Composition of non-starch polysaccharides (NSP) of experimental diets $(\mathrm{g} / \mathrm{kg} \text { diet })^{*}$

\begin{tabular}{|c|c|c|c|c|c|c|}
\hline \multirow[t]{2}{*}{ Diet ... } & \multicolumn{2}{|c|}{ Low-fibre } & \multicolumn{2}{|c|}{ High-fibre } & \multicolumn{2}{|c|}{ High-fibre, finely ground } \\
\hline & Insoluble & $\begin{array}{l}\text { Soluble + } \\
\text { insoluble }\end{array}$ & Insoluble & $\begin{array}{l}\text { Soluble + } \\
\text { insoluble }\end{array}$ & Insoluble & $\begin{array}{c}\text { Soluble }+ \\
\text { insoluble }\end{array}$ \\
\hline Rhamnose & $1 \cdot 8$ & $3 \cdot 1$ & $2 \cdot 8$ & $4 \cdot 4$ & $2 \cdot 8$ & $4 \cdot 2$ \\
\hline Arabinose & $7 \cdot 5$ & $10 \cdot 6$ & $11 \cdot 4$ & $16 \cdot 0$ & $11 \cdot 3$ & $15 \cdot 8$ \\
\hline Xylose & $28 \cdot 4$ & $28 \cdot 4$ & 43.9 & $45 \cdot 1$ & 43.6 & $44 \cdot 4$ \\
\hline Mannose & 5.9 & 5.9 & $9 \cdot 9$ & 10.8 & 9.9 & $10 \cdot 9$ \\
\hline Galactose & 4.7 & $7 \cdot 3$ & $7 \cdot 6$ & $11 \cdot 4$ & 7.6 & $11 \cdot 1$ \\
\hline Glucose & $104 \cdot 5$ & $104 \cdot 5$ & $161 \cdot 8$ & $161 \cdot 8$ & $160 \cdot 7$ & $160 \cdot 7$ \\
\hline Uronic acids & $29 \cdot 2$ & $48 \cdot 3$ & $46 \cdot 1$ & $72 \cdot 2$ & $45 \cdot 8$ & $67 \cdot 9$ \\
\hline Total NSP & 1820 & $208-1$ & $283 \cdot 5$ & $321 \cdot 7$ & $281 \cdot 7$ & $315 \cdot 0$ \\
\hline
\end{tabular}

* For details, see Table 1 and p. 134.

Table 4. Characteristics of growth, digesta contents and visceral organ weights of rabbits, after the adaptation period to the experimental diets*

\begin{tabular}{|c|c|c|c|c|}
\hline Diet... & Low-fibre & High-fibre & SED & $\begin{array}{c}\text { Statistical } \\
\text { significance } \\
\text { of difference : } \\
P\end{array}$ \\
\hline \multicolumn{5}{|l|}{ Growth } \\
\hline Initial wt (g) (4 weeks of age) & 667 & 707 & $32 \cdot 4$ & $0 \cdot 404$ \\
\hline Slaughter wt (g) (11 weeks of age) & 2033 & 2194 & $85 \cdot 5$ & $0 \cdot 202$ \\
\hline Daily wt gain $(\mathrm{g})$ & $27 \cdot 9$ & $30 \cdot 4$ & {$[\cdot 4$} & 0.227 \\
\hline Daily feed $(\mathrm{g})$ & 89 & 123 & $4 \cdot 3$ & 0.001 \\
\hline Feed: wt gain & $3 \cdot 2$ & $4 \cdot 1$ & $0 \cdot 1$ & $0 \cdot 001$ \\
\hline \multicolumn{5}{|l|}{ Organ wt $(g)$} \\
\hline Stomach & $15 \cdot 3$ & $17 \cdot 4$ & $0 \cdot 6$ & $0 \cdot 035$ \\
\hline Caecum & $25 \cdot 8$ & $29 \cdot 9$ & $1 \cdot 4$ & 0.051 \\
\hline Proximal colon & $13 \cdot 5$ & $14 \cdot 5$ & $0 \cdot 4$ & $0 \cdot 122$ \\
\hline \multicolumn{5}{|l|}{ Digesta contents (g) } \\
\hline Stomach & $51 \cdot 8$ & $68 \cdot 8$ & $4 \cdot 2$ & $0 \cdot 018$ \\
\hline Caecum & $88 \cdot 1$ & 107.8 & $4 \cdot 1$ & 0.004 \\
\hline Proximal colon & $10 \cdot 2$ & $13 \cdot 0$ & 0.8 & $0 \cdot 142$ \\
\hline Faecal dry matter $(\mathrm{g} / \mathrm{kg})$ & 674 & 533 & 15 & 0.001 \\
\hline
\end{tabular}

SED, standard error of the difference, ( $16 \mathrm{df}$, except for faecal dry matter, $8 \mathrm{df}$ ).

* For details of diets and procedures, see Table 1 and p. 134.

Arabinose, galactose and uronic acids, which are the typical monomers of pectic substances in lucerne, were the most digested $\mathrm{CW}$ components $(65-80 \%)$. About half the digested pectic substances could be accounted for by water-soluble NSP, but values of concentrations (Table 1) showed that even water-insoluble pectic substances were more digested than xylose or glucose units. Thus, mean faecal digestibility of total pectin components (sum of arabinose, rhamnose, galactose and uronic acids) reached $72 \%$, without significant changes for diet or group effect. As the NDF residue did not include the highly digested fraction of $\mathrm{CW}$, i.e. pectic substances and water-soluble $\mathrm{CW}$, digestibility values were always lower than those for total NSP. 
T. GIDENNE

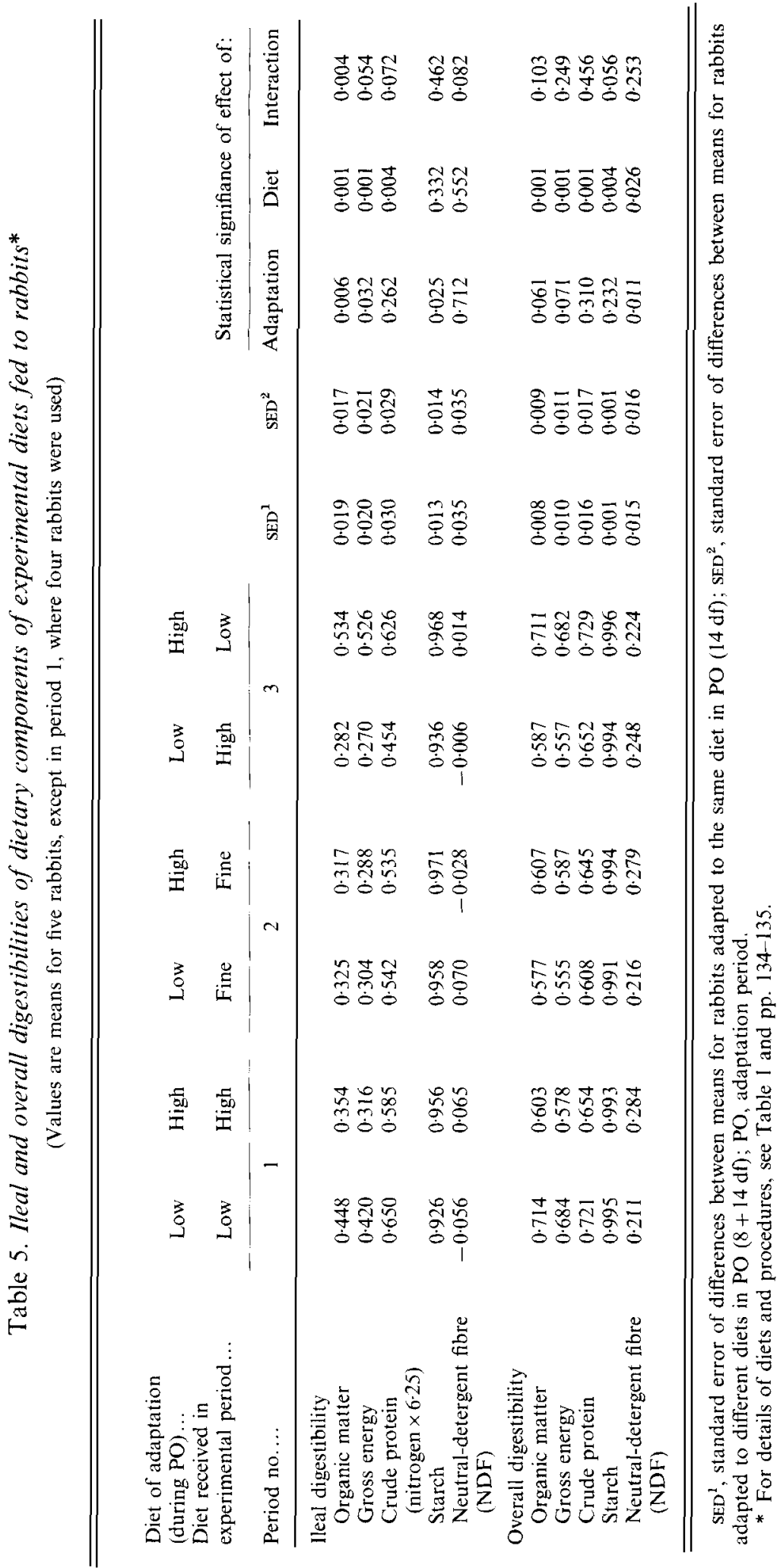


FIBRE, DIGESTIBILITY AND RATE OF PASSAGE IN RABBIT

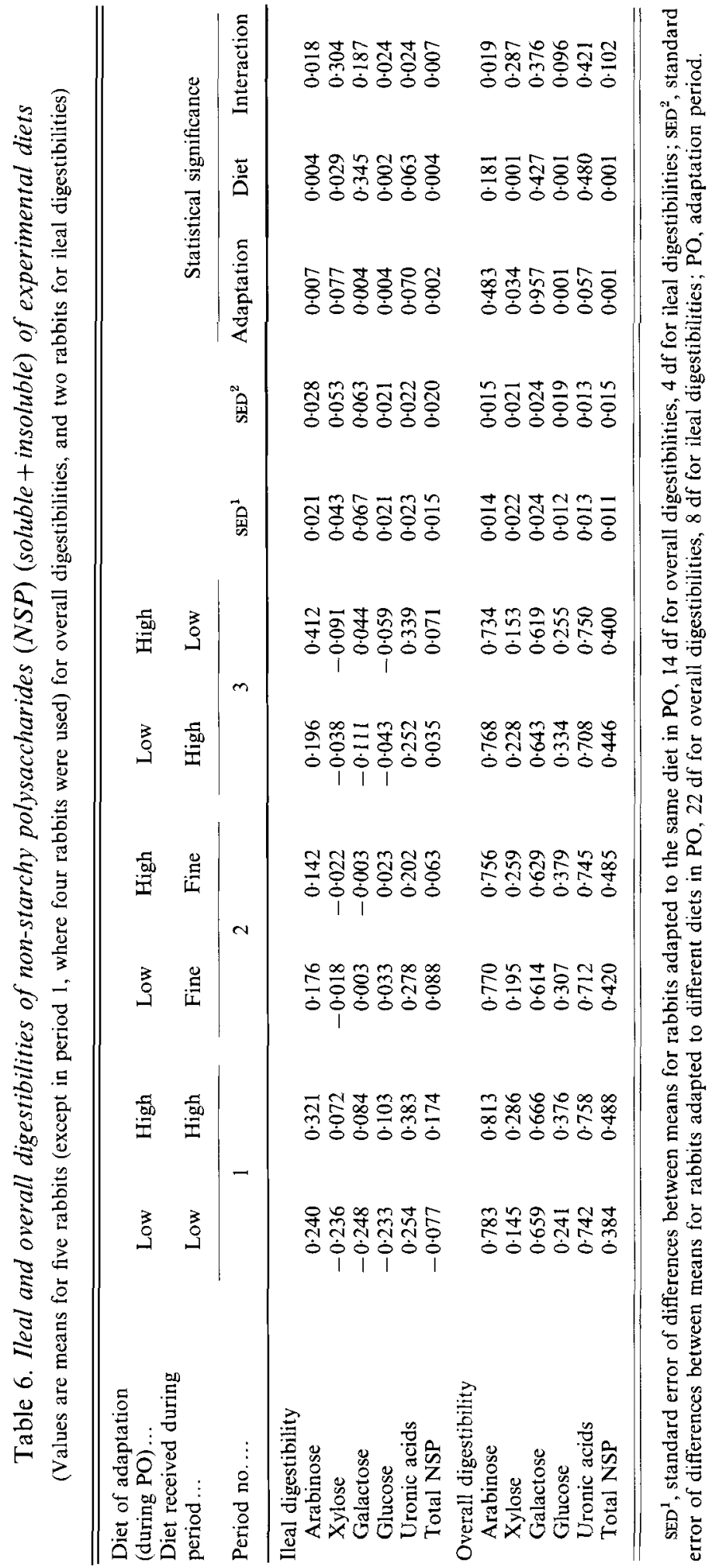




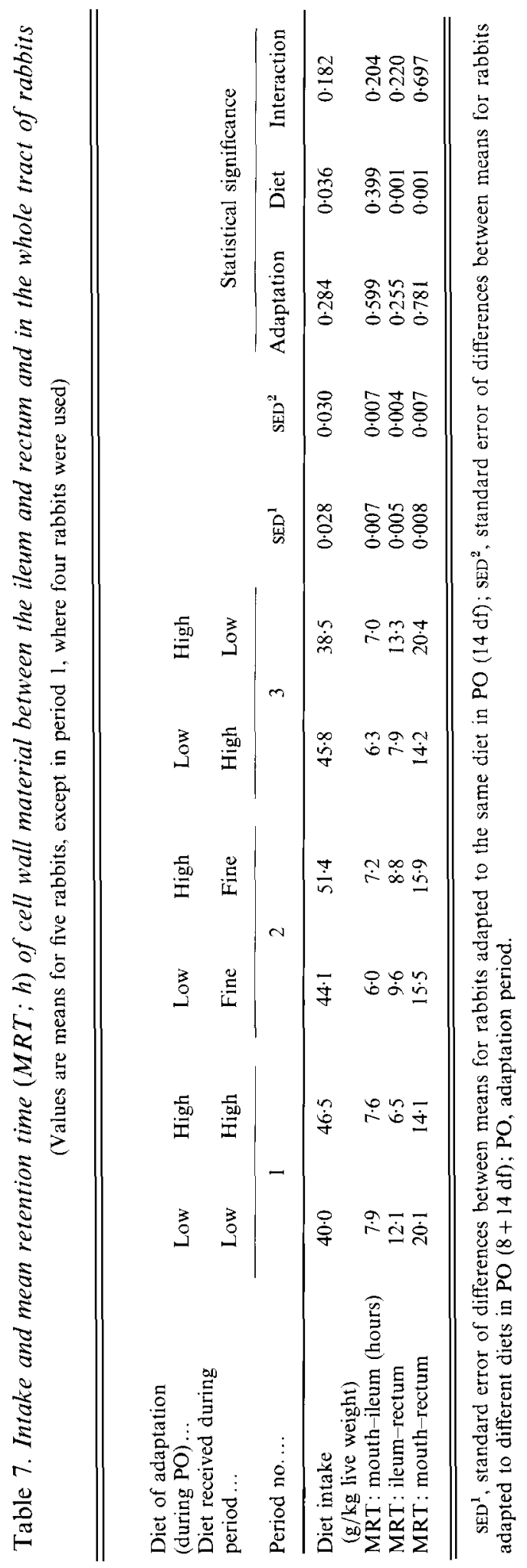


Measurements of digesta flow at the terminal ileum allowed IDC to be estimated and compared with those values obtained in the whole tract for the same rabbits. Values for OM or energy were similar and varied from 35 to $45 \%$ according to the level of CW (Table 5). As ileal digestibility was related to the extent of digestion in the whole tract, it was better to compare the proportions of nutrients digested before the caecum to estimate digestive efficiency in the small intestine. Thus, $60 \%$ of the digested OM was apparently digested before the caecum, and a slight reduction in group LL compared to group HH was found: 58.7 and $62.7 \%$ respectively. The amount of crude protein flowing at the ileum remained low and similar $(13 \mathrm{~g} / \mathrm{d})$ for the two groups; the digestible fraction of crude protein was almost entirely digested in the small intestine $(90 \%)$, even for diet $\mathrm{H}$ which contained mainly protein from lucerne. Starch was incompletely degraded before the caecum. Increasing its proportion in the diet (diet L) significantly increased the quantity of starch reaching the caecum, but it remained very low: $3 \cdot 2 v .1 \cdot 0 \mathrm{~g} / \mathrm{d}$ for diets $\mathrm{L}$ and $\mathrm{H}$ respectively.

$\mathrm{CW}$ estimated by the NDF method (insoluble CW except pectic components) appeared to be undegraded before the caecum, with no effect of the level of LM. Values obtained for total NSP (water-soluble and insoluble $\mathrm{CW}$ ) showed a low level of $\mathrm{CW}$ degradation $(0-17 \%)$ in the small intestine (Table 6). Xylose and glucose remained undegraded. Neutral and acidic sugars of pectic substances were apparently hydrolysed at an extent of $20-40 \%$ of the intake, and about $50 \%$ of digestible pectin disappeared before the caecum.

MRT for the particulate phase of the diet (Table 7) measured in the whole tract (MRTt) was greatly reduced for rabbits receiving diet $\mathrm{H}(14 \mathrm{~h})$ compared with that for those fed on diet $\mathrm{L}(20 \mathrm{~h})$. This effect originated mainly from a reduction in ileo-rectal transit time: 12 and $6 \mathrm{~h}$ for groups LL and HH respectively. Thus, the MRT in the stomach and small intestine was not significantly modified by the effect of fibre level.

\section{Effect of fibre particle size}

As expected, the pellets of diet $F$ (Table 2) contained no large particles (size $>1 \mathrm{~mm}$ ) and a lower proportion of particles over $0.3 \mathrm{~mm}$ compared with diet $\mathrm{H}$. The granulometric profile of diet $F$ was intermediate between those of diets $L$ and $H$.

At the same level of dietary fibre, grinding LM through a $1 \mathrm{~mm}$ screen did not significantly influence ileal or faecal digestibilities of dietary constituents, except for the IDC of uronic acids which was reduced significantly (Table 6) for rabbits of group HF compared with that for group $\mathrm{HH}$.

Total MRT was increased after grinding LM $(+1 \cdot 8 \mathrm{~h})$. This effect was mainly due to a longer transit time in the distal part of the tract, without significant changes in diet intake (Table 7) between diets $\mathrm{H}$ and $\mathrm{F}$.

\section{Effect of adaptation to dietary fibre level}

The effect of adaptation was significant $(P<0 \cdot 1)$ for faecal digestibility of OM and energy for rabbits fed on diet $\mathrm{H}$ during growth, which seemed to digest high-fibre diets (diets $\mathrm{F}$ or H) more efficiently. This effect was not due to changes in starch or crude protein digestion, but lower fibre degradation was observed, as shown by NDF or total NSP digestibility coefficients, for rabbits receiving diets L during PO. Lower cellulose (non-starch glucose) and xylose FDC were measured for animals adapted to diet $\mathrm{L}$. Adaptation to diet $\mathrm{H}$ significantly improved the efficiency of the digestion of pectic components of $L M$, whereas there was no effect of fibre level on FDC.

The effect of adaptation to fibre level also modified some variables of digestion in the small intestine. Rabbits initially fed on diet L (high starch level) had a lower IDC for starch irrespective of the diet they were fed later. In addition, rabbits of group HL had 
significantly higher IDC values (OM and energy) than those of group LL. Highly digestible components of NSP were also affected by PO : rabbits adapted to diet $\mathrm{H}$ had higher IDC for uronic acids, galactose and arabinose in diets $\mathrm{L}$ and $\mathrm{H}$.

The effect of adaptation to the level of LM was not significant for MRT values in the whole tract or in the ileo-rectal segment.

DISCUSSION

The increase in the empty weight of the stomach and caecum of rabbits fed on diet $\mathrm{H}$ during growth (4-11 weeks of age) suggests physical adaptation of the digestive tract to the increase in diet intake (bulking effect of increasing proportions of LM). Such an effect was not observed previously in rabbits by Lebas et al. (1982), probably because the adaptation period was too short ( 4 weeks). However, the bulking effect of fibre on the development of digestive organs has been reported for other non-herbivorous simple-stomached species, i.e. the pig (Kass et al. 1980; Pond et al. 1988) and the rat (Rémesy \& Demigne, 1989). The increase in fresh digesta contents for all organs could be a result of a higher diet intake by rabbits fed on diet $\mathrm{H}$, but the higher water-holding capacity of the high-fibre diet would also contribute, as shown by the lower DM content of faeces.

The decrease in the faecal digestibility of $\mathrm{OM}$ and energy with increasing dietary proportions of LM was in general agreement with results obtained with simple-stomached animals. This was mainly due to the dilution effect of CW because of their low DE content. Simultaneous measurement of rate of passage (MRT) allows us to show another effect of $\mathrm{CW}$, which seemed to act in addition to the first one. Thus, our results and previous findings in the pig (Kuan et al. 1983; Ravindran et al. 1984; Roth \& Kirchgessner, 1985) indicated that high dietary fibre level reduced MRT in the whole tract, reducing the time available for enzyme degradation.

Very few studies have attempted to measure rate of passage in different digestive segments, especially in simple-stomached herbivorous animals. Our findings suggest that the effect of fibre level on variations in the rate of passage originated mainly from variations in MRT between ileum and rectum. Any changes in the rate of passage in the small intestine were related to the LM level, and small variations in the efficiency of digestion in this segment were observed for digestible constituents. Starch was almost entirely digested before the caecum, as has been found in pigs (Darcy et al. 1981; Graham et al. 1986). High amounts of protein were digested before the caecum irrespective of diet. Protein from LM $(700 v .400 \mathrm{~g} / \mathrm{kg}$ protein respectively in diets $\mathrm{H}$ and $\mathrm{L}$ ) was digested to a lesser extent than that from fish-concentrate meal. It would be expected that the origin of protein added to an eventual fibre effect (decreasing small intestine MRT) would induce variations in the efficiency of the digestion, but proportions of the digestible crude protein apparently absorbed before the caecum were similar for each diet.

Degradation of CW was reduced for diet $\mathrm{L}$, the low-fibre high-starch diet, as shown by two different methods of CW analysis: gravimetric method (Van Soest \& Wine, 1967) or colorimetric and gas-liquid chromatographic analysis of sugars from fibre polysaccharides. Changes in CW faecal digestibility seemed to be due mainly to the water-insoluble fraction of polysaccharides: glucose and xylose were better digested in diet $\mathrm{H}$, and they were absent from the water-soluble CW of LM. Digestion of pectic material remained very high for all the diets. Water-soluble pectic substances represent $40 \%$ of total pectin in LM. Considering that water-soluble pectic substances were entirely degraded, $55 \%$ of water-insoluble pectic substances would be degraded without differences related to the level of $\mathrm{CW}$. This absence of variation in degradation of pectic materials could be explained by their faster degradation rate compared with those of other CW polysaccharides (Chesson \& Monro, 1982). However, Chabeauti \& Noblet (1989) reported in pig trials that there were no 
changes in NDF digestion but a decrease in digestion of pectic material with increasing levels of wheat bran. Kuan et al. (1983) observed no significant variations in CW degradation when pigs were fed on diets containing high $v$. low LM content. Our results obtained with adult rabbits were confirmed by a trial conducted on growing rabbits with the same diet. A positive effect of increasing dietary LM content on NDF digestibility was also observed and it was related to higher caecal volatile fatty acid concentrations (Gidenne \& Scalabrini, 1990).

Two main nutritional factors are susceptible to change: caecal fermentation and therefore, fibre degradation. First, the amount of rapidly fermentable nutrients (protein, available carbohydrates) which would be able to reach fermentative compartments (caecum and proximal colon for rabbit) must be considered because of their ability to modify caecal $\mathrm{pH}$ and flora. Second, the turnover rate (inverse of rate of passage) of digesta contents in these digestive segments must also be considered. Measurements of digesta flow performed at the ileum gave some evidence for a small effect of the first factor. The amounts of starch reaching the caecum were different between groups $\mathrm{HH}$ and $\mathrm{LL}$, but they remained at a very low level $(<2.5 \mathrm{~g} / \mathrm{d})$. Similarly, ileal flow of protein did not differ relative to fibre level. On the other hand, the lower turnover rate (higher MRT) measured in the caecum and proximal colon for rabbits fed on diet $\mathrm{L}$ could be related to the lower $\mathrm{CW}$ degradation. Our findings suggest that CW hydrolysis would be reduced if the removal of digesta (equivalent to the inverse of MRT) was too low to provide a sufficient supply of readily fermentable substrate and fibre polysaccharides. In addition, it is generally assumed that positive correlation between digestive volume and fibre degradation would exist. Effectively, our findings suggested that an enlargement in digestive organs of the distal part of the tract (caecum and colon of rabbits adapted to diet $\mathrm{H}$ ) would contribute to a higher fibre degradation.

IDC of NDF residues (water-insoluble CW, except pectic substances) were similar between diets and were not significantly different from zero. This was in agreement with the general idea of fibre indigestibility in the proximal part of the gastrointestinal (GI) tract. However, the IDC of CW obtained with a more specific method showed that large amounts of arabinose and uronic acids disappeared before the caecum, whereas xylose and glucose units ( $75 \%$ of dietary water-insoluble $\mathrm{CW}$ ) were almost totally recovered at the ileum (over $90 \%$ ). CW degradation before the posterior part of the GI tract was also reported in ileostomized man (Sandberg et al. 1981) and in pigs with an ileo-rectal shunt (Laplace et al. 1989; Chabeauti \& Noblet, 1990) or with a T-shaped cannula (Millard \& Chesson, 1984). Cellulolytic activity was also found in the small intestine of pigs (Chesson et al. 1985). Our findings obtained with rabbits suggest that the fibre fraction which was susceptible to hydrolysis to a relatively large extent in the small intestine would probably be mainly water-soluble pectic components.

It is generally assumed that particle size does affect susceptibility of fibre to bacterial degradation but the findings of earlier studies in the rabbit are inconsistent. Laplace \& Lebas (1977) found an increase in DM digestibility when the same diet was subject to regrinding, whereas Lebas et al. (1986) reported no significant effect of a fine grinding of the raw material on the digestibility of the dietary constituents. Our results showed that for the same level of $\mathrm{CW}$, reduction in particle size did not improve $\mathrm{CW}$ digestibility in spite of a longer retention time in the caeco-colic segments. This contradicts the proposal, essentially based on results obtained with ruminants, that fibre degradation is improved by improved contact between bacterial enzymes and $\mathrm{CW}$. A possible explanation for results obtained with the rabbit was that anti-peristaltic movements of the proximal colon would be enhanced by fine grinding (Bouyssou et al. 1988) contributing to the higher MRT of fine particles (size $<0.3 \mathrm{~mm}$ ), water-soluble constituents and bacteria. Thus, the turnover rate 
of caecal contents was decreased and, as suggested previously, this would impair CW degradation. This effect would balance the effect of reducing fibre particle size which was supposed to increase CW degradation. This absence of effect of particle size on $\mathrm{CW}$ degradation obtained in herbivorous simple-stomached species was also found in pigs (Ehle et al. 1982) and rats (Nyman \& Asp, 1985) when using coarse or fine wheat bran.

In conclusion, dietary fibre level affects digestive efficiency in the small intestine, without variations in the rate of passage. Our study has also shown that the digestive tract of the rabbit adapts to the fibre content of the diet with changes in the rate of passage and digestibility. Further experiments will be conducted using different sources of $\mathrm{CW}$, in order to confirm these preliminary conclusions with LM. However, it will be useful to employ our experimental model for studying in vivo enzymic and fermentative digestion.

The author wishes to thank Bernard Carré (Station de Recherche Avicole, INRA Tours) for his helpful advice and assistance in performing cell wall analyses, Joëlle Gomez (Station de Recherche Avicole, INRA Tours) for her technical assistance in cell wall analyses, André Lapanouse and Murielle Ségura for technical assistance (Laboratoire de recherche sur l'Elevage du Lapin, INRA Toulouse), Annick Moisan (Biometry and Artificial Intelligence Station, INRA Toulouse) for his help in statistical analyses and Rebecca Dickstein (Department of Bioscience and Biotechnology, Drexel University, Philadelphia, USA) for helpful criticism in the preparation of the manuscript.

The present work was supported by a grant from INRA for a coordinated programme (AIP no. 90/4725) on the physiology of metabolic and fermentative activity after dietary fibre ingestion.

\section{REFERENCES}

Björnhag, G. (1972). Separation and delay of contents in the rabbit colon. Swedish Journal of Agricultural Research 2, 125-136.

Blakeney, B., Harris, P. J., Henry, R. J. \& Stone, B. A. (1983). A simple and rapid preparation of alditolacetate for monosaccharide analysis. Carbohydrate Research 113, 291-299.

Blumenkrantz, N. \& Asboe-Hansen, G. (1973). New method for quantitative determination of uronic acids. Analytical Biochemistry 54, 484-489.

Bouyssou, T., Candau, M. \& Ruckebush, Y. (1988). Réponses motrices du côlon aux constituants pariétaux et $\dot{a}$ la finesse de mouture des aliments chez le lapin. (Colonic motility pattern according to the source of fibre and to the grinding level of the diet, in the rabbit.) Reproduction Nutrition Développement 28, 181-182.

Carré, B., Prévotel, B. \& Leclercq, B. (1984). Cell wall content as a predictor of metabolisable energy value of poultry feedingstuffs. British Poultry Science 25, 561572.

Chabeauti, E. \& Noblet, J. (1990). Digestion par le porc en croissance de quatres sources de parois végétales utilisées seules ou en association. (Digestion in the growing pig of four sources of fibre used alone or in association.) Journée de la Recherche Porcine 22, $167 \cdots 174$.

Chesson, A. \& Monro, F. A. (1982). Legume pectic substances and their degradation in the ovine rumen. Journal of the Science of Food and Agriculture 33, 852-859.

Chesson, A., Richardson, A. J. \& Robertson, J. A. (1985). Fibre digestion and bacteriology of the digestive tract of pigs fed cereals and vegetable fibre. In Digestive Physiology in the Pig. National Institute for Animal Science. Report no. 580, pp. 272-275. Copenhagen: National Institute for Animal Science.

Darcy, B., Laplace, J. P. \& Villiers, P. A. (198I). Digestion dans l'intestin grêle chez le porc. (4) Cinétique de passage des digesta au niveau de la jonction ileo-caeco-colique et bilans de la digestion selon la nature de l'amidon et la source de protéines alimentaires. (Digestion in the small intestine of the pig. (4) Digesta flow measurements at the ileo-caeco-colic junction and digestibility according to starch and protein source.) Annales de Zootechnie 30, 31-62.

Ehle, F. R., Jeraci, J. L., Robertson, J. B. \& Van Soest, P. J. (1982). The influence of dietary fiber on digestibility, rate of passage and gastrointestinal fermentation in pigs. Journal of Animal Science 55, 1071-1081.

Ellis, W. C. \& Beever, D. E. (1985). Methods for binding rare earths to specific feed particles. In Techniques in Particle Size Analysis of Feed and Digesta in Ruminants. Canadian Society of Animal Science Occasional Publication no. 1, pp. 154-165 [P. M. Kennedy, editor]. Edmonton: Canadian Society of Animal Science.

Fadel, J. G., Newmann, K. R., Newmann, C. W. \& Graham, H. (1989). Effects of baking huless barley on the digestibility of dietary components as measured at the ileum and in the faeces in pigs. Journal of Nutrition 119 , $722-726$. 
Faichney, G. J. (1975). The use of markers to partition digestion within the gastro-intestinal tract of ruminants Digestion and Metabolism in the Ruminant, pp. 227-241 [I. W. McDonald and A. C. I. Warner, editors]. Armidale: University of New England.

Gidenne, T. (1987). Effet de l'addition d’un concentré riche en fibres dans une ration à base de foin. distribuée à deux niveaux alimentaires chez la lapine adulte. (2) Mesures de digstibilité. (Effect of the addition of a fibre-rich concentrate to a hay-based diet offered at two levels of feeding to adult rabbits. (2) Digestibility measurements.) Reproduction Nutrition Développement 27, 801-810.

Gidenne, T. (1988). Mesures du flux iléal chez le lapin: comparaison de l'ytterbium et du chrome mordancé et representativité des digesta receuillis. (Ileal flow measurements in the rabbit: comparison between ytterbium and mordanted chromium and representivity of ileal samples.) Reproduction Nutrition Développement 28. Suppl. 1, 153-154.

Gidenne, T., Bouyssou, T. \& Ruckebusch, Y. (1988). Sampling of digestive contents by ileal canulation in the rabbit. Animal Production 46, 147-151.

Gidenne, T. \& Lebas, F. (1987). Estimation quantitative de la caecotrophie chez le lapin en croissance: variations en fonction de l'âge. (Quantitative estimation of caecotrophy in the growing rabbit: variations with age.) Annales de Zootechnie 36, 225-236.

Gidenne, T. \& Ruckebusch, Y. (1989). Flow and rate of passage studies at the ileal level in the rabbit. Reproduction Nutrition Développement 29, 403-412.

Gidenne, T. \& Scalabrini, F. (1990). Digestion des constituants pariétaux et activité fermentaire caecale chez le lapin en croissance: incidence du taux d'incorporation et de la granulométrie de la source de fibre. (Fibre digestion and caecal fermentation for the growing rabbit: effect of level of incorporation and grinding of the fibre source.) bème Journées de la Recherche sur la Nutrition et l'alimentation des Herbivores, Communication no. 27. Paris: Institut Nationale Agronomique.

Giger, S., Sauvant, D., Dorléans, M. \& Morand-fehr, P. (1979). Détermination semi-automatique des constituants membranaires des aliments concentrés par la méthode de van Soest. (Semi-automatic determination of cell wall constituents in concentrate feeds using the van Soest method.) 30th Annual meeting of the European Association for Animal Production. Harrogate, England: Commission of Animal Feeding, N 3.5.

Graham, H., Hesselman, K. \& Aman, P. (1986). The influence of wheat bran and sugar-beet pulp on the digestibility of dietary components in a cereal-based diet. Joumal of Nutrition 116, 242-251.

Kass, M. L., Van Soest, P. J., Pond, W. G., Lewis, B. \& McDowell, R. E. (1980). Utilisation of dietary fiber from alfalfa by growing swine. 1. Apparent digestibility of diet components in specific segments of the gastrointestinal tract. Journal of Animal Science 50, 175-191.

Kuan, K. K., Stanogias, G. \& Dunkin, A. C. (1983). The effect of proportion of cell-wall material from lucerne meal on apparent digestibility, rate of passage and gut characteristics in pigs. Animal Production 36, 201-209.

Laplace, J. P., Darcy-Vrillon, B., Perez, J. M., Henry, Y., Giger, S. \& Sauvant, D. (1989). Associative effects between two fibre sources on ileal and overall digestibilities of aminoacids and cell-wall components in growing pigs. British Journal of Nutrition 61, 75-87.

Laplace, J. P. \& Lebas, F. (1977). Le transit digestif chez le lapin. (7) Influence de la finesse de broyage des constituants d'un aliment granulé. (Rate of passage in the rabbit. (7) Effect of the grinding level of a pelleted diet.) Annales de Zootechnie 26, 413-420.

Lebas, F., Laplace, J. P. \& Droumenq, P. (1982). Effets de la teneur en énergie de l'aliment chez le lapin. Variations en fonction de l'âge des animaux et de la séquence des régimes alimentaires. (Effect of dietary energy content in the rabbit. Variations according to age of animals and feeding sequences.) Annales de Zootechnie 31, $233-256$.

Lebas, F., Maitre, I., Seroux, M. \& Franck, T. (1986). Influence du broyage des matières premières avant agglomération de 2 aliments pour lapins différant par leur taux de constituants menbraniares: digestibilité et performances de croissance. (Effect of the grinding of raw material before pelleting for two rabbit diets differing in their level of fibre: digestibility and growth.) 4èmes Journées de la Recherche Cunicole, Communication no. 9, pp. 9.1-9.13. Paris: Institut Technique de l'Aviculture.

Longland, A. C., Close, W. H. \& Low, A. G. (1989). The role of the large intestine in influencing the use of fibrous feeds by pigs. In Nutrition and Digestive Physiology in Monogastric Farm Animals, pp. 111-114. Wageningen: PUDOC.

Longstaff, M. \& McNab, J. M. (1989). Digestion of fibre polysaccharides of pea (Pisum sativum) hulls, carrot and cabbage by adult cockerels. British Journal of Nutrition 62, 563-577.

Millard, P. \& Chesson, A. (1984). Modifications to swede (Brassica napus L.) anterior to the terminal ileum of pigs: some implications for the analysis of dietary fibre. British Journal of Nutrition 52, 583-594.

Nyman, M. \& Asp, N. G. (1985). Dietary fibre fermentation in the rat intestinal tract: effect of adaptation period, protein and fibre levels, and particle size. British Journal of Nutrition 54, 635-643.

Pond, W. G., Jung, H. G. \& Varel, V. H. (1988). Effect of dietary fiber on young adult genetically lean, obese and contemporary pigs : body weight, carcass measurements, organ weights and digesta content. Journal of Animal Science 66, 699-706.

Ravindran, V., Kornegay, E. T. \& Webb, K. E. (1984). Effects of fiber and virginiamycin on nutrient absorption, nutrient retention and rate of passage in growing swine. Journal of Animal Science 59, $400-407$.

Rémésy, C. \& Démigné, C. (1989). Effet des polysaccharides de soja ou de betterave sur le développement des fermentations caecales chez le rat. (Effect of polysaccharides from soya or beet-pulp on fermentative activity in the caecum of the rat.) Réunion de T Association Française de Nutrition, 30-31 May. Nantes: A.F.N. 
Roth, F. X. \& Kirchgessner, M. (1985). Digestibility and intestinal transit rate in pigs in relation to plane of feeding and crude fiber content of the diet. Zeitschrift für Tierphysiologie, Tierernährung und Futtermitelkunde $\mathbf{5 3}, 254-256$.

Sandberg, A. S., Andersson, H., Hallgren, B., Hasselblad, K., Isaksson, B. \& Hulten, L. (1981). Experimental model for in vivo determination of dietary fiber and its effect on the absorption of nutrients in the small intestine. British Journal of Nutrition 45, 283-294.

Statistical Analysis System (1985). SAS/STAT. Guide for Personnal Computers, version 6. Cary, NC: SAS Institute Inc.

Van Soest, P. J. \& Wine, R. H. (1967). Use of detergents in the analysis of fibrous feeds. 4. Determination of plant cell-wall constituent. Journal of the Association of Official Agricultural Chemists 50, 50-55.

Printed in Great Britain

\section{SUBMITTING PAPERS}

Papers should be sent to Professor D. A. T. Southgate, British Journal of Nutrition, 10 Cambridge Court, 210 Shepherds Bush Road, Hammersmith, London W6 7NJ. They should be written concisely and must represent the results of original nutritional research (or exceptionally a new interpretation of existing knowledge) not previously published. Full requirements and details of how papers should be prepared are given in Directions to Contributors printed in Part 1 of each volume but authors should also consult a recent issue to acquaint themselves with the style and conventions of the Journal. Submitted papers (three copies) should be accompanied by a signed statement to the effect that the author accepts the conditions laid down in Directions to Contributors. 